\title{
A Case Report on Hypervitaminosis D Mediated Juvenile Idiopathic Arthritis
}

\author{
Arunkumar S ${ }^{1}$, Mebin Alias ${ }^{2}$, Cindy Jose ${ }^{3}$, Venkateswaramurthy $\mathbf{N}^{4}$ \\ ${ }^{1}$ Student, J.K.K. Nattraja College of Pharmacy, Kumarapalayam, Namakkal, Tamilnadu, India. \\ ${ }^{2}$ Assistant Professor, Department of Pharmacy Practice, J.K.K. Nattraja College of Pharmacy, Kumarapalayam, \\ Namakkal, Tamilnadu, India. \\ ${ }^{3}$ Assistant Professor, Department of Pharmacy Practice, J.K.K. Nattraja College of Pharmacy, Kumarapalayam, \\ Namakkal, Tamilnadu, India. \\ ${ }^{4}$ Head, Department of Pharmacy Practice, J.K.K. Nattraja College of Pharmacy, Kumarapalayam, Namakkal, \\ Tamilnadu, India.
}

Corresponding Author: S. Arunkumar

\begin{abstract}
Juvenile Idiopathic Arthritis (JIA) may be defined as prevailing persistent rheumatic malady of unknown etiology in childhood and predominantly presents with peripheral arthritis. Oligoarticular Juvenile Idiopathic Arthritis (OJIA) was prevailing betwixt young female patients which consistently accompanied by anti-nuclear antibodies incontrovertibility and anterior uveitis. Disease complications differ from maturation retardation, osteoporosis and bone deformities. Due to severe Macrophage Activation System (MAS) leads to multi-organ insufficiency and loss of function. The primary goals of treatment are to distribute normal joint function, to perpetuate normal growth and to thwart longterm joint damage and retain normal body homeostasis.
\end{abstract}

Keywords: Juvenile Idiopathic Arthritis, Vitamin D Toxicity, Hypercalciuria, Hypervitaminosis

\section{INTRODUCTION}

Juvenile idiopathic arthritis is a diverse group of conditions in which beset whole assemble of arthritis of anonymous aetiology abiding for partially 6 weeks along with outset ahead the age of 16 years. ${ }^{[1]}$ Its disclosed incidence and prevalence in European and North American populations length from 2 to 20 and from 16 to 150 per 100,000, respectively. [2] The global prevalence of JIA is predicted to be from 0.07 to 4.1 per 1000 children, with an incidence of 0.008 to 0.226 cases of JIA per 1000 children. ${ }^{[3]}$ The downturn of Vitamin $D$ results in cell proliferation and raise cell differentiation, pause the development of new blood vessels, and has compelling antiinflammatory effects. ${ }^{[4]}$ Immense vitamin D concentrations were fraction as more prone to be diagnosed with colon cancer as compare to downturn concentrations. Even the world literature has scanty reported that prolonged use have like confusion, apathy, recurrent vomiting, polyuria, polydipsia, pallor and abdominal pain, are better often noted clinical symptoms of Vitamin D Toxicity. Physicians should assess the patient condition frequently to avert the breakthrough of adverse events, which progress the patient condition physically and economically. Primary management incorporate proper diagnosis, reduction of risk factors, discontinuation of offending drugs and supportive medical management. [6]

\section{CASE REPORT}

The 9 years old female patient of 20 $\mathrm{Kg}$ was admit to the hospital in Pediatric 
Ward. She had complaints of joint edema, pain in between the wrist joints particularly carpometacarpal joint and metacarpophalangeal joint in left hand for past 6 months. She was conscious, oriented and active on admission. She used to take health Syrup which contained rich vitamin D for past 5 years, but stopped for last six month. After two weeks, she experienced symptoms like skin rashes, allergy to sunlight, urinary tract infection and nocturnal polyuria. Her lab investigation showed that random blood sugar $79 \mathrm{mg} / \mathrm{dl}$, blood urea $28 \mathrm{mg} / \mathrm{dl}$, serum creatinine $0.6 \mathrm{mg} / \mathrm{dl}$, white blood cells 9,300cells/cu.mm, hemoglobin $11.7 \mathrm{mg} / \mathrm{dl}$ and Urine calcium (hypercalciuria) was present. She was diagnosed with juvenile idiopathic arthritis and was confirmed by Anti-Nuclear Antibodies Positivity. Initially the child was treated with Tab. Paracetamol 500mg trice a day, Tab Brufen 100mg twice a day, T. Ranitidine 150mg twice a day, T. $\mathrm{B}$ vitamin complex $33.5 \mathrm{mg}$ twice a day for 5 days. On day 7, there was symptomatic improvement and reduction in pain was seen in child and was discharged.

\section{DISCUSSION}

Hypercalciuria is a severe, potentially lethal risk factor of childhood metabolic disorders, primarily Systemiconset juvenile idiopathic arthritis. It is characterized by urolithiasis, gross or microscopic hematuria, countermand symptoms (urinary urgency, incontinence, dysuria, pollakiuria, enuresis and suprapubic pain), urinary tract infection, furthermore flank, or abdominal pain in the non appearance of urolithiasis and less prevalence, acute renal colic. ${ }^{[7-8]}$ The British Pediatric Association documented hypercalcemia only in isolated cases of infants who had approximate daily vitamin D intakes of 1,500-1,725 IU. [9] The ingestion of disproportionate laid off vitamin $\quad \mathrm{D}_{3}$ (or vitamin $\mathrm{D}_{2}$ ) may consequence in hypercalcemia and hypercalciuria as long to the development of supraphysiological volume of $25(\mathrm{OH}) \mathrm{D}$. That dilemma to the vitamin $\mathrm{D}$ receptor, not with standing with reduce affinity than the effective form of $1,25(\mathrm{OH})_{2} \mathrm{D}$. ${ }^{[10-13]}$ The classified IH into three definite pathogenetic pathways, bestow tosovereign primary metabolic defects: (1) absorptive hypercalciuria type I, when constitutional intestinal hyperabsorption of calcium is involved; (2) absorptive hypercalciuria type III, when a elementary renal leak of phosphate is instant, thus activating hypophosphatemia and secondarily 1,25 $(\mathrm{OH})_{2}$ vitamin D-mediated intestinal hyperabsorption of calcium; and (3) renal hypercalciuria. In one study by Tarak Srivastava, they disclosed incidence of hypercalciurea which cause Dent's disease. ${ }^{[14]}$ Up to 100 cases have been disclosed in the literature until 2002. In one study by Gabriella Giancane, it is recorded that incidence and prevalence of JIA in European and North American populations length from 2 to 20 and from 16 to 150 per 100,000 respectively. [15] Although hypercalciurea generally develops in the early phase of JIA, it has been known to occur up to 10 years after diagnosis. The symptoms produced are compatible with the biological effects of several $\mathrm{T}$ lymphocyte and macrophage-derived pro-inflammatory cytokines such as tumour necrosis factor (TNF) $\alpha$, interleukin (IL)-1, 6 and interferon $\gamma$, skin rashes, allergy to sunlight, urinary tract infection and nocturnal polyuria, AntiNuclear Antibodies Positivity. [16-20] Differential diagnosis of systemic juvenile idiopathic arthritis are Infection like viral infections, Septicemia, Bacterial endocarditis, Brucellosis, Typhoid fever ${ }^{\text {[21- }}$ 24] and some Anti-Inflammatory Syndromes like Sarcoidosis, Castleman Disease, Inflammatory Bowel Disease, Systemic vasculitis, Systemic lupus erythematosus, Kawasaki syndrome, Scleroderma, Marfan Syndrome, Neuroblastoma, Lymphoma. ${ }^{[25-}$

\section{CONCLUSION}

This case report pinpoint that Hypervitaminosis D induced JIA can last for indefinite weeks to month later en-scene of 
drug. Hence, physicians should assess the patient condition frequently to avert the development of adverse events, which improves patient condition physically and economically. Primary management incorporate proper diagnosis, reduction of risk factors, discontinuation of offending drugs and supportive medical management. Instead of using only Vitamin D syrup, multivitamin syrup, rich vitamin food supplementation which has lowest propensity to cause JIA symptoms can be used based on the patient condition.

\section{Abbreviation:}

MAS - Macrophage Activating Syndrome

$1,25(\mathrm{OH})_{2} \mathrm{D}-$ Calcitriol

VDT - Vitamin D Toxicity

SoJIA - Systemic Obstructive Juvenile idiopathic arthritis

\section{ACKNOWLEDGEMENT}

We have extended our thanks to Head, Department of General Medicine, Tertiary Care Hospital, Erode \& Principal, J.K.K. Nattraja College of Pharmacy, Kumarapalyam for their support and encouragement for writing this case report.

\section{Conflict of Interest: None}

\section{Source of Funding: None}

\section{REFERENCES}

1. Kenan B, Amra A, Sezgin S and Ozgur K. Juvenile Idiopathic Arthritis, Balkan Med J, 2017; 34(2): 90-101.

2. Heiliczer JD, Canonigo BB, Bishof NA, Moore ES. Non calculi urinary tract disorders secondary to idiopathic hypercalciuria in children. PediatrClin North Am.1987; 34: 711-8.

3. Penido MG, Diniz JS, Moreira ML, et al. Idiopathic hypercalciuria: presentation of 471 cases. J Pediatr, 2001; 77: 101-104.

4. Alon US, Berenbom A. Idiopathic hypercalciuria of childhood: 4- to 11-year outcome. Pediatr Nephrol. 2000; 14:10111015.

5. Polito C, La Manna A, Cioce F, Villani J, Nappi B. Clinical presentation and natural course of idiopathic hypercalciuria in children. PediatrNephrol. 2000; 15: 211214.

6. Vachvanichsanong P, Malagon M, Moore ES. Urinary tract infection in children associated with idiopathic hypercalciuria. Scand J UrolNephrol. 2001; 35: 112-116.

7. Alon US, Zimmerman $\mathrm{H}$, Alon $\mathrm{M}$. Evaluation and treatment of pediatric idiopathic urolithiasis-revisited. Pediatr Nephrol. 2004; 19: 516-520.

8. Srivastava T, Schwaderer A. Diagnosis and management of hypercalciuria in children. CurrOpinPediatr. 2009; 21: 214-219.

9. Marcinowska-Suchowierska E, KupiszUrbańska $M$ and et al. Vitamin D ToxicityA Clinical Perspective. Frontiers in endocrinology, 2018; 9: 550.

10. Tebben PJ, Singh RJ, \& Kumar R. Vitamin D-Mediated Hypercalcemia: Mechanisms, Diagnosis, and Treatment. Endocrine reviews, 2016; 37(5): 521-547.

11. Lindner G, Felber R, Schwarz C. Hypercalcemia in the ED: prevalence, etiology, and outcome. Am J Emerg Med. 2013; 31: 657-660.

12. Greenberg A, Piraino BM, Bruns FJ. Hypercalcemia in patients with advanced chronic renal failure not yet requiring dialysis. Am J Nephrol. 1989; 9: 205-210.

13. Brommage R, De Luca HF. Evidence that 1 , 25-dihydroxyvitamin D3 is the physiologically active metabolite of vitamin D3. Endocr Rev. 1985; 6: 491-511.

14. Srivastava T, Alon US. Pathophysiology of hypercalciuria in children. PediatrNephrol. 2007; 22: 1659-1673.

15. Giancane G, Consolaro A. Juvenile Idiopathic Arthritis: Diagnosis and Treatment, RheumatolTher. 2016; 3: 187207.

16. Muller D, Hoenderop JG, Merkx GF, and et al. Gene structure and chromosomal mapping of human epithelial calcium channel. BiochemBiophys Res Commun, 2000; 275: 47-52.

17. Peng JB, Chen XZ, Berger UV, and et al. Molecular cloning and characterization of a channel-like transporter mediating intestinal calcium absorption. J BiolChem, 2000; 274: 22739-22746.

18. Hoenderop JG, Hartog A, Stuiver M, and et al. Localization of the epithelial $\mathrm{Ca}(2+)$ channel in rabbit kidney and intestine. J Am SocNephrol, 2000; 11: 1171-1178. 
19. Hoenderop JG, Vennekens R, Muller D, and et al. Function and expression of the epithelial $\mathrm{Ca}(2+)$ channel family: comparison of mammalian $\mathrm{ECaCl}$. J Physiol, 2000; 537: 747-761.

20. Frick KK, Bushinsky DA. Molecular mechanisms of primary hypercalciuria. $\mathrm{J}$ Am SocNephrol, 2003; 14:1082-1095.

21. Loffing J, Loffing-Cueni D, Valderrabano $\mathrm{V}$, et al. Distribution of transcellular calcium and sodium transport pathways along mouse distal nephron. Am J Physiol Renal Physiol, 2001; 281: F1021-F1027.

22. Reilly RF, Ellison DH. Mammalian distal tubule: physiology, pathophysiology, and molecular anatomy. Physiol Rev, 2000; 80: 277-313.

23. Suki WN. Calcium transport in the nephron. Am J Physiol, 1979; 237: F1-F6.

24. Shimizu T, Yoshitomi K, Nakamura M, Imai M. Effects of PTH, calcitonin, and cAMP on calcium transport in rabbit distal nephron segments. Am J Physiol, 2004; 259: F408-F414.

25. Bindels RJ, Hartog A, Timmermans J. Van Os $\mathrm{CH}$, Active $\mathrm{Ca} 2+$ transport in primary cultures of rabbit kidney CCD: stimulation by 1,25-dihydroxyvitamin D3 and PTH. Am J Physiol, 2000; 261: F799-F807.

26. Hoenderop JG, van Leeuwen JP, van der Eerden $\mathrm{BC}$, et al. Renal $\mathrm{Ca} 2+$ wasting, hyperabsorption, and reduced bone thickness in mice lacking TRPV5. J Clin Invest, 2003; 112: 1906-1914.

27. Kiessling U, Doring E, Listing J, and et al. Incidence and prevalence of juvenile chronic arthritis in East Berlin 1980-88. The Journal of rheumatology, 1998; 25(9): 1837-1843.

How to cite this article: Arunkumar S, Alias M, Jose $\mathrm{C}$ et.al. A case report on hypervitaminosis $\mathrm{D}$ mediated juvenile idiopathic arthritis. Int $J$ Health Sci Res. 2021; 11(5): 349-352. DOI: https://doi.org/10.52403/ijhsr.20210554 